\title{
Analysis of organic acids of tricarboxylic acid cycle in plants using GC-MS, and system modeling
}

\author{
Vinod Kumar ${ }^{1,2^{*}}$, Anket Sharma $^{1,2 \dagger}$, Renu Bhardwaj ${ }^{2}$ and Ashwani Kumar Thukral ${ }^{2}$
}

\begin{abstract}
Background: Leaves of 15 plant species were collected from the catchment areas of the river Beas, Punjab, India, and analyzed for organic acids of tricarboxylic acid cycle, viz., citric acid (CA), succinic acid (SA), fumaric acid (FmA), and malic acid (MA).

Methods: Gas chromatography-mass spectrometry (GC-MS) was used to determine the content of organic acids in the leaves of plant species. Two microliters of plant sample was injected into the GC-MS, and the concentration of organic acids was quantified using standard curve.

Results: Average concentrations of these acids in the leaves of plants studied were $4.79,0.98,0.54$, and $8.36 \mathrm{mg} / \mathrm{g} \mathrm{dw}$, respectively. The maximum contents of these acids were found in the leaves of Chenopodium album (CA $=6.42 \mathrm{mg} / \mathrm{g}$ $\mathrm{dw}$ ), Argemone mexicana ( $\mathrm{SA}=1.27$ and $\mathrm{FmA}=0.73 \mathrm{mg} / \mathrm{g} \mathrm{dw}$ ), and Rumex dentatus ( $\mathrm{MA}=18.0 \mathrm{mg} / \mathrm{g} \mathrm{dw}$ ). Factor analysis revealed mainly two underlying factors for organic acids: Factor-1 having maximum loadings on SA and FmA and Factor-2 had maximum loadings on CA and MA. Multiple linear regression analysis of MA on other acids showed that CA and SA have positive regressions, whereas FmA has a negative regression on MA. In artificial neural network analysis, correlation between the target and output values of MA was found to be highly significant. System transfer coefficients were calculated from simulation graphs fitted to the mean values of different organic acids by using difference equations.

Conclusions: From the present study, it was found that citric acid has a maximum direct effect on the malic acid as compared to succinic and fumaric acids as revealed by path analysis. System modeling revealed that the rate of utilization of malic acid is about 9\%. The present study describes a new system simulation technique in which a pathway comprising of linear transformation of biochemical constituents may be characterized in terms of its rate transfer coefficients.
\end{abstract}

Keywords: Krebs cycle, Citric acid, Succinic acid, Fumaric acid, Malic acid, Simulation, System analysis

\section{Background}

Organic acids are important metabolites of the tricarboxylic acid cycle in plants, which is the main energyproducing cycle of the cell. Analysis of organic acids is important because of their involvement in various physiological activities of plants (Bennet-Clark 1993). The organic acid contents in the leaves of plants vary with species and on the degree of development or

\footnotetext{
* Correspondence: vinodverma507@gmail.com

${ }^{\dagger}$ Equal contributors

'Department of Botany, DAV University, Sarmastpur, Jalandhar, Punjab 144012, India

${ }^{2}$ Department of Botanical \& Environmental Sciences, Guru Nanak Dev University, Amritsar, Punjab 143005, India
}

maturation of plants, the environment, and many other factors. Since environmental or agronomic practices may affect the expression of genes in the seeds, these may also affect the organic acid contents (Kader 2008). Citric acid is a tricarboxylic acid and is mainly present in citrus fruits. It is used as a food additive to give acidity and sour taste to food and beverages (Destandau et al. 2005). Malic acid is a dicarboxylic acid, and it provides a pleasant taste and is also used as a food additive (Carocho et al. 2013; Campo et al. 2006). It plays an important role in improving the performance of muscles, reducing tiredness, as well as in improving mental clarity (Baldwin 2002). Nogués et al. (2006) reported that the leaves of 
Ranunculus glacialis contained high malic acid content. Fumaria parviflora, Argemone mexicana, Rumex dentatus, Polygonum barbatum, and Polygonum plebeium plants are rich sources of polyphenols as well as amino acids (Kumar et al. 2015a, b). Arias-Carmona et al. (2014) studied the contents of ascorbic acid, malic acid, oxalic acid, and citric acid in Brassica rapa leaves. Sánchez-Mata et al. (2012) studied the contents of citric acid, malic acid, and fumaric acid in Foeniculum vulgare, Chondrilla juncea, Cichorium intybus, Taraxacum obovatum, Beta maritime, and Papaver rhoeas. The present study was designed to study variations in the organic acid contents, i.e., citric acid (CA), succinic acid (SA), fumaric acid (FmA), and malic acid (MA) using gas chromatography-mass spectrometry (GC-MS) in the leaves of 15 plant species collected from the catchment areas of the river Beas, India. Multivariate techniques such as principal component analysis, factor analysis, multiple linear regression analysis, and artificial neural network analysis were applied to the contents of different organic acids. System simulation techniques were applied to determine system transfer functions from one acid to the next at steady state.

\section{Methods}

\section{Study area}

The river Beas originates in the southern side of the Rohtang Pass above Kullu in Beas Kund, in central Himachal Pradesh, India $\left(32.36^{\circ} \mathrm{N}\right.$ lat. and $77.08^{\circ} \mathrm{E}$ long.) and merges into river Sutlej at Harike $\left(31.17^{\circ} \mathrm{N}\right.$ lat. and $75.2^{\circ} \mathrm{E}$ long.) in the state of Punjab, India, after traversing a distance of about $470 \mathrm{~km}$. Plant samples were collected from the surroundings of the river bed between the towns of Beas and Harike. Identification and authentication of the plants was done at the Botanical Survey of India, Dehradun, India.

\section{Organic acids quantification using GC-MS Preparation of sample}

The organic acids in the plant leaves were determined by following the procedure earlier described by Sharma et al. (2016). Organic acids were extracted from $50 \mathrm{mg}$ of the oven dried $\left(80{ }^{\circ} \mathrm{C}, 24 \mathrm{~h}\right)$ powdered leaves of different plant species by adding $0.5 \mathrm{ml}$ of $0.5 \mathrm{~N} \mathrm{HCl}$ and $0.5 \mathrm{ml}$ of methanol. After that, the samples were shaken for $3 \mathrm{~h}$ followed by centrifugation at $12,000 \mathrm{rpm}$ for $10 \mathrm{~min}$. To the supernatant, $300 \mu \mathrm{l}$ of methanol and $100 \mu \mathrm{l}$ of $50 \%$ sulphuric acid were added followed by overnight incubation in water bath at $60{ }^{\circ} \mathrm{C}$. The mixture was cooled down to $25{ }^{\circ} \mathrm{C}$, and $800 \mu \mathrm{l}$ of chloroform and $400 \mu \mathrm{l}$ of distilled water were added to it followed by vortexing for $1 \mathrm{~min}$. The lower chloroform layer was used to estimate organic acids using GC-MS.

\section{Investigation using GC-MS}

For the determination of organic acids, $2 \mu$ lof plant sample, i.e., the lower chloroform layer, was injected in the system. GC conditions: Helium was used as carrier gas, the starting column temperature was $50{ }^{\circ} \mathrm{C}$ held for 1 min which was raised to $125{ }^{\circ} \mathrm{C}$ at $25^{\circ} \mathrm{C} /$ min followed by additional enhancement to $300{ }^{\circ} \mathrm{C}$ at $10{ }^{\circ} \mathrm{C} / \mathrm{min}$, held for $15 \mathrm{~min}$. Injection temperature was $250{ }^{\circ} \mathrm{C}$, injection mode was split, gas flow in the column was $1.7 \mathrm{ml} / \mathrm{min}$, and analytical column DB-5ms was used. MS conditions: Ion source temperature was set at $200{ }^{\circ} \mathrm{C}$ and interface temperature was $280{ }^{\circ} \mathrm{C}$, solvent cut time was $3 \mathrm{~min}$, and detector gain mode was relative. Since the sample preparation procedure resulted in the derivatization of organic acids, the studied organic acids were citric acid trimethylester, succinic acid dimethyester, fumaric acid dimethyester, and malic acid dimethyester, and their contents were estimated using standard curve.

\section{Simulation of rate transfer coefficients}

The rates of change of different components may be described by a system of linear differential equations for a constant size of the first component viz. citric acid $\left(x_{1}\right)$ to malic acid $\left(x_{4}\right)$.

$$
\begin{aligned}
& \frac{d x_{2}}{d t}=a x_{1}-b x_{2} \\
& \frac{d x_{3}}{d t}=b x_{2}-c x_{3} \\
& \frac{d x_{4}}{d t}=c x_{3}-d x_{4}
\end{aligned}
$$

where $x_{i}$ are the concentrations of the acids and $a, b, c$, and $d$ are the rates of transfer from one component to the next one. The differential equations can be solved for the size of the component with respect to time. With time, the system will tend to a steady state, and the rate of change of each component will be zero:

$$
\frac{d x_{i}}{d t}=0
$$

The system can be simulated using a set of difference equations:

$$
\begin{aligned}
& x_{2}(t+1)=x_{2}(t)+a x_{1}(t)-b x_{2}(t) \\
& x_{3}(t+1)=x_{3}(t)+b x_{2}(t)-c x_{3}(t) \\
& x_{4}(t+1)=x_{4}(t)+c x_{3}(t)-d x_{4}(t)
\end{aligned}
$$

where $x_{i}(t)$ and $x_{i}(t+1)$ are the sizes of the components at times $(t)$ and $(t+1)$, respectively. The matrix model representation of the difference equations given above will be as follows: 


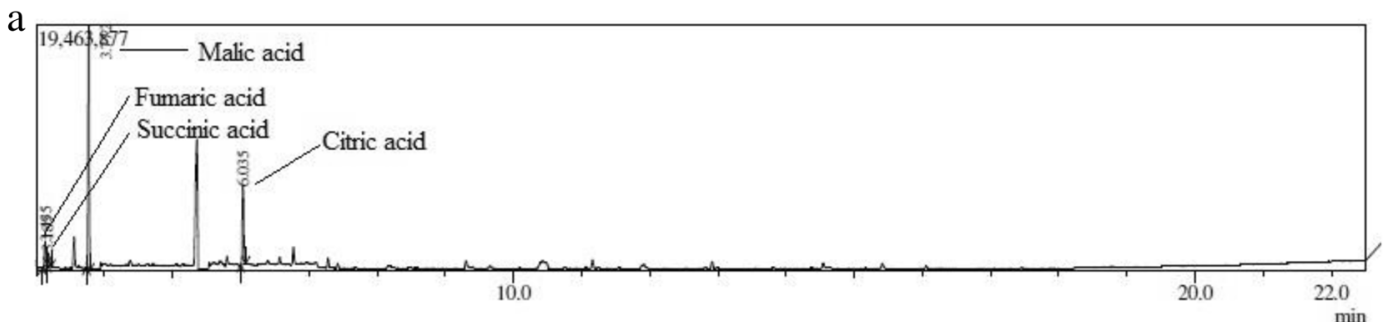

b
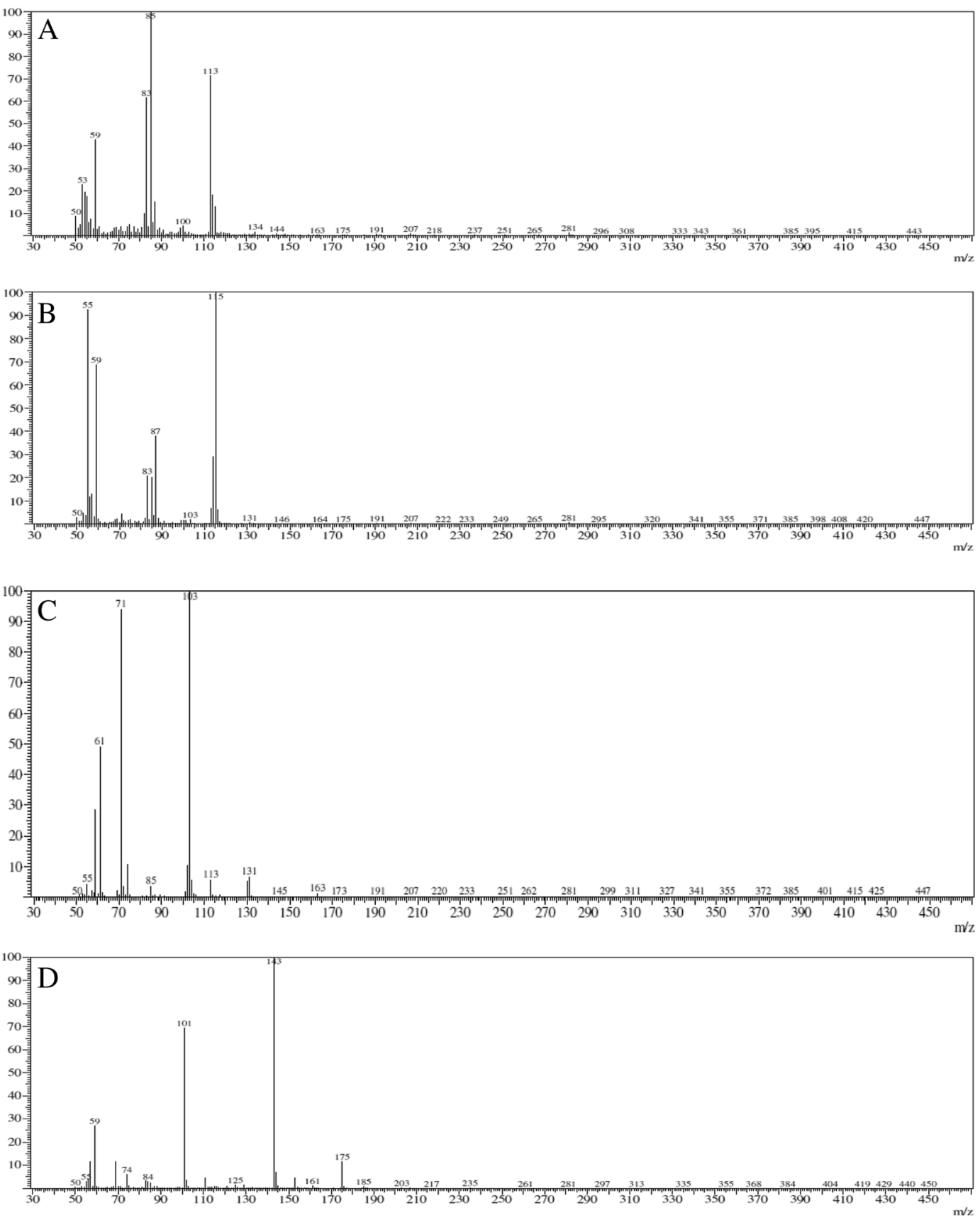

Fig. 1 a Total ion chromatogram of organic acid using GC-MS analysis. b Mass spectrums of organic acids obtained after GC-MS analysis. Fumaric acid dimethyester $(A)$, succinic acid dimethyester $(B)$, malic acid dimethylester, $(C)$ and citric acid trimethylester $(D)$ 
Table 1 Mean and standard deviation $(n=3)$ of organic acids in the leaves of plants collected from catchment areas of the river Beas

\begin{tabular}{|c|c|c|c|c|c|c|}
\hline Plant species & Family & $C A(m g / g d w)$ & $\mathrm{SA}(\mathrm{mg} / \mathrm{g} \mathrm{dw})$ & $\mathrm{FmA}(\mathrm{mg} / \mathrm{g} \mathrm{dw})$ & $M A(m g / g d w)$ & $\begin{array}{l}\text { Total acids } \\
\text { (mg/g dw) }\end{array}$ \\
\hline Ranunculus sceleratus L. & Ranunculaceae & $5.78 \pm 0.017$ & $0.88 \pm 0.002$ & $0.59 \pm 0.006$ & $12.3 \pm 0.28$ & 19.61 \\
\hline Argemone mexicana $\mathrm{L}$. & Papaveraceae & $4.04 \pm 0.006$ & $1.27 \pm 0.013$ & $0.73 \pm 0.007$ & $7.66 \pm 0.17$ & 13.70 \\
\hline Fumaria parviflora Lam. & Papaveraceae & $3.55 \pm 0.024$ & $0.86 \pm 0.002$ & $0.44 \pm 0.0002$ & $6.19 \pm 0.56$ & 11.04 \\
\hline Oxalis corniculata L. & Oxalidaceae & $3.85 \pm 0.026$ & $0.95 \pm 0.010$ & $0.43 \pm 0.001$ & $6.20 \pm 0.42$ & 11.43 \\
\hline Ageratum conyzoides $\mathrm{L}$. & Asteraceae & $5.77 \pm 0.055$ & $0.95 \pm 0.009$ & $0.48 \pm 0.003$ & $4.95 \pm 0.30$ & 12.16 \\
\hline Erigeron bonariensis $\mathrm{L}$. & Asteraceae & $4.32 \pm 0.072$ & $0.98 \pm 0.007$ & $0.50 \pm 0.006$ & $6.90 \pm 0.21$ & 12.69 \\
\hline Parthenium hysterophorus L. & Asteraceae & $4.41 \pm 0.042$ & $1.01 \pm 0.018$ & $0.51 \pm 0.004$ & $9.52 \pm 0.56$ & 15.46 \\
\hline Chenopodium album $\mathrm{L}$. & Amaranthaceae & $6.42 \pm 0.067$ & $0.94 \pm 0.001$ & $0.57 \pm 0.008$ & $6.47 \pm 0.02$ & 14.40 \\
\hline Chenopodium ambrosioides L. & Amaranthaceae & $4.61 \pm 0.053$ & $1.01 \pm 0.009$ & $0.57 \pm 0.009$ & $8.20 \pm 2.11$ & 14.39 \\
\hline Polygonum barbatum L. & Polygonaceae & $4.55 \pm 0.057$ & $1.02 \pm 0.033$ & $0.58 \pm 0.009$ & $5.16 \pm 0.45$ & 11.31 \\
\hline Polygonum plebeium R.Br. & Polygonaceae & $4.28 \pm 0.122$ & $0.94 \pm 0.014$ & $0.61 \pm 0.010$ & $5.41 \pm 0.47$ & 11.24 \\
\hline Rumex dentatus $\mathrm{L}$. & Polygonaceae & $6.25 \pm 0.145$ & $0.95 \pm 0.004$ & $0.55 \pm 0.002$ & $18.0 \pm 1.22$ & 25.82 \\
\hline Tamarix dioica Roxb. ex Roth & Tamaricaceae & $5.10 \pm 0.089$ & $1.10 \pm 0.013$ & $0.70 \pm 0.010$ & $8.18 \pm 0.41$ & 15.07 \\
\hline Cannabis sativa $\mathrm{L}$. & Cannabaceae & $5.15 \pm 0.060$ & $0.97 \pm 0.016$ & $0.47 \pm 0.008$ & $14.61 \pm 0.56$ & 21.20 \\
\hline Typha angustata Chamb. & Typhaceae & $3.81 \pm 0.035$ & $0.96 \pm 0.022$ & $0.44 \pm 0.002$ & $5.68 \pm 0.25$ & 10.89 \\
\hline Average & & 4.792 & 0.986 & 0.544 & 8.362 & \\
\hline
\end{tabular}

$C A$ citric acid, SA succinic acid, FmA fumaric acid, MA malic acid

$$
\left[\begin{array}{l}
x_{1}(t+1) \\
x_{2}(t+1) \\
x_{3}(t+1) \\
x_{4}(t+1)
\end{array}\right]=\left[\begin{array}{cccc}
1 & 0 & 0 & 0 \\
a & 1-b & 0 & 0 \\
0 & b & 1-c & 0 \\
0 & 0 & c & 1-d
\end{array}\right]\left[\begin{array}{l}
x_{1}(t) \\
x_{2}(t) \\
x_{3}(t) \\
x_{4}(t)
\end{array}\right]
$$

or

$$
X(t+1)=M X(t)
$$

where $M$ is the rate transfer matrix and $X(t)$ and $X(t+1)$ are vectors for organic acid contents at times $(t)$ and $(t+1)$, respectively. At steady state,

$$
X(t+1)=X(t)
$$

The system of difference equations was simulated using a self-coded software in MS-Excel to determine the rate transfer coefficients $a, b$, and $c$, by inputting the values of $x_{1}, x_{2}, x_{3}, x_{4}$, and $d$.

\section{Statistical analysis}

All the analyses were done in triplicate, and the results were expressed in mean and standard deviation values. The data were analyzed by using principal component analysis (PCA), factor analysis (FA), multiple linear regression analysis (MLR), and artificial neural network analysis (ANN) (Sokal and Rohlf 1995; Bailey 1994; Kumar et al. 2016, 2017). First-order linear difference equations were used for the simulation of the transformation of acids to a steady state. System analysis software was coded in MS-Excel. The software used were PAST, Minitab-14, and Statistica-12.

\section{Results and discussion}

The chromatogram and mass spectra of organic acids are given in Fig. 1a, b. The means and standard deviations of organic acids studied are given in Table 1. Maximum citric acid content was found in Chenopodium album (6.42 $\mathrm{mg} / \mathrm{g} \mathrm{dw}$ ) followed by Rumex dentatus $(6.25 \mathrm{mg} / \mathrm{g} \mathrm{dw})$. Argemone mexicana recorded maximum contents of succinic acid $(1.27 \mathrm{mg} / \mathrm{g} \mathrm{dw})$ and fumaric acid $(0.73 \mathrm{mg} / \mathrm{g} \mathrm{dw})$. Rumex dentatus recorded maximum content of malic acid $(18.0 \mathrm{mg} / \mathrm{g} \mathrm{dw})$. Maximum content of the four organic acids was found in Rumex dentatus ( $25.82 \mathrm{mg} / \mathrm{g} \mathrm{dw}$ ) followed by Cannabis sativa $(21.2 \mathrm{mg} / \mathrm{g} \mathrm{dw})$, whereas the lowest amount of total organic acids was found in Typha angustata $(10.89 \mathrm{mg} / \mathrm{g} \mathrm{dw})$. The trend of variation of the organic acids in the plants studied was malic acid > citric acid > succinic acid > fumaric acid. Adamczak et al. (2012)

Table 2 Factor analysis of different organic acids

\begin{tabular}{llll}
\hline Variable & Factor-1 & Factor-2 & Communality \\
\hline CA & 0.016 & -0.880 & 0.775 \\
SA & 0.921 & 0.161 & 0.874 \\
FmA & 0.922 & -0.166 & 0.878 \\
MA & -0.012 & -0.842 & 0.709 \\
\% variance & 42.5 & 38.4 & 80.9 \\
\hline
\end{tabular}



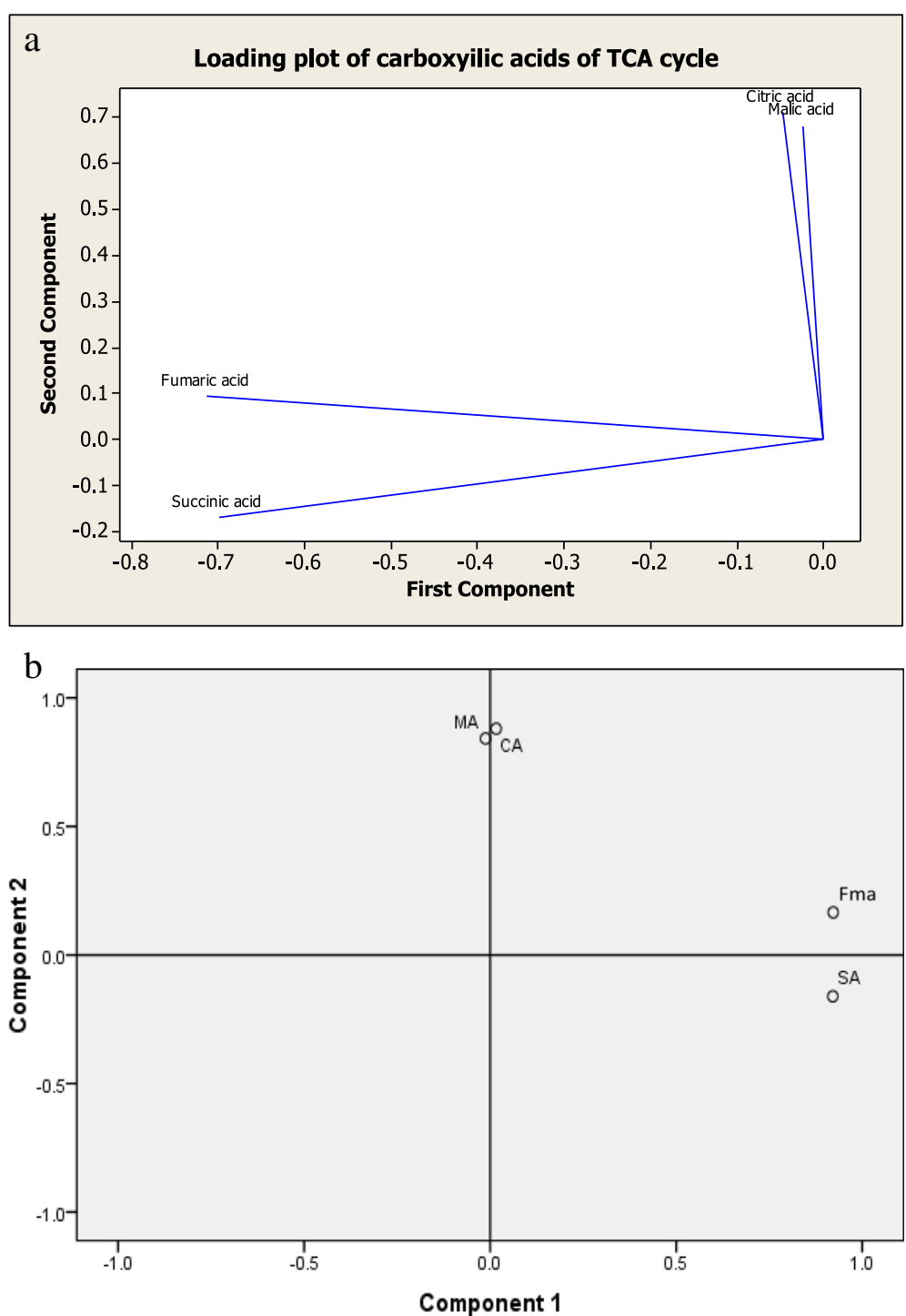

Fig. 2 a Loading plot of PCA for intermediate acids (SA and FmA) and source-sink acids (CA, MA). b Score plot of PCA for intermediate acids (SA and FmA) and source-sink acids (CA, MA)

reported citric acid contents in different species of rose, viz., Rosa agrestis $(1.08 \mathrm{mg} / \mathrm{g} \mathrm{dw})$, R. thodora $(1.95 \mathrm{mg} / \mathrm{g}$ $\mathrm{dw}$ ), and R. jundzillu (2.90 mg/g dw). Roriz et al. (2014) reported malic acid contents in Pterospartum tridentatum (3.23 mg/g dw), Cymbopogon citratus $(2.23 \mathrm{mg} / \mathrm{g}$ $\mathrm{dw})$, and Gomphrena globosa (12.33 mg/g dw). They also analyzed citric acid contents in P. tridentatum $(5.99 \mathrm{mg} / \mathrm{g}$ $\mathrm{dw})$ and G. globosa $(2.40 \mathrm{mg} / \mathrm{g} \mathrm{dw})$ and fumaric acid contents in G. globosa $(0.28 \mathrm{mg} / \mathrm{g} \mathrm{dw})$ and C. citratus (0.49 $\mathrm{mg} / \mathrm{g} \mathrm{dw})$. Nogués et al. (2006) studied the carbon metabolism by labeling the Ranunculus glacialis with ${ }^{13} \mathrm{C} /{ }^{12} \mathrm{C}$-isotope ratio mass spectrometry and ${ }^{13} \mathrm{C}$-nuclear magnetic resonance. It was observed that malic acid is not utilized by respiration, when leaves are labeled with ${ }^{13} \mathrm{C}$-depleted $\mathrm{CO}_{2}$ or $\mathrm{H}^{13} \mathrm{CO}_{3}^{-}$. However, the
Table 3 Multiple regression and path analyses of organic acids of TCA cycle

Multiple regression equation

MA $(\mathrm{mg} / \mathrm{g} \mathrm{dw})=-4.16+2.28 \mathrm{CA}(\mathrm{mg} / \mathrm{g} \mathrm{dw})+4.99 \mathrm{SA}(\mathrm{mg} / \mathrm{g} \mathrm{dw})-6.01$ $\mathrm{FmA}(\mathrm{mg} / \mathrm{g} \mathrm{dw})$

Multiple correlation coefficient $(r)=0.5010(p<0.001)$

Path analysis

Independent Direct effects Indirect effects (IE) on MA Total effects

variables (DE) on MA CA SA FmA Total IE

$\begin{array}{lllllllllll}\text { Citric acid } & 0.5393 & 0 & - & - & - & 0.4924\end{array}$

$\begin{array}{llll}\text { (CA) } & 0.0204 & 0.0265 & 0.0469\end{array}$

$\begin{array}{llllllll}\text { Succinic } & 0.1252 & - & 0 & - & - & -0.0604\end{array}$

acid (SA) $\quad 0.0879 \quad 0.0976 \quad 0.1856$

$\begin{array}{lllllll}\text { Fumaric } & -0.1398 & 0.1024 & 0.0874 & 0 & 0.1899 & 0.0501\end{array}$ 


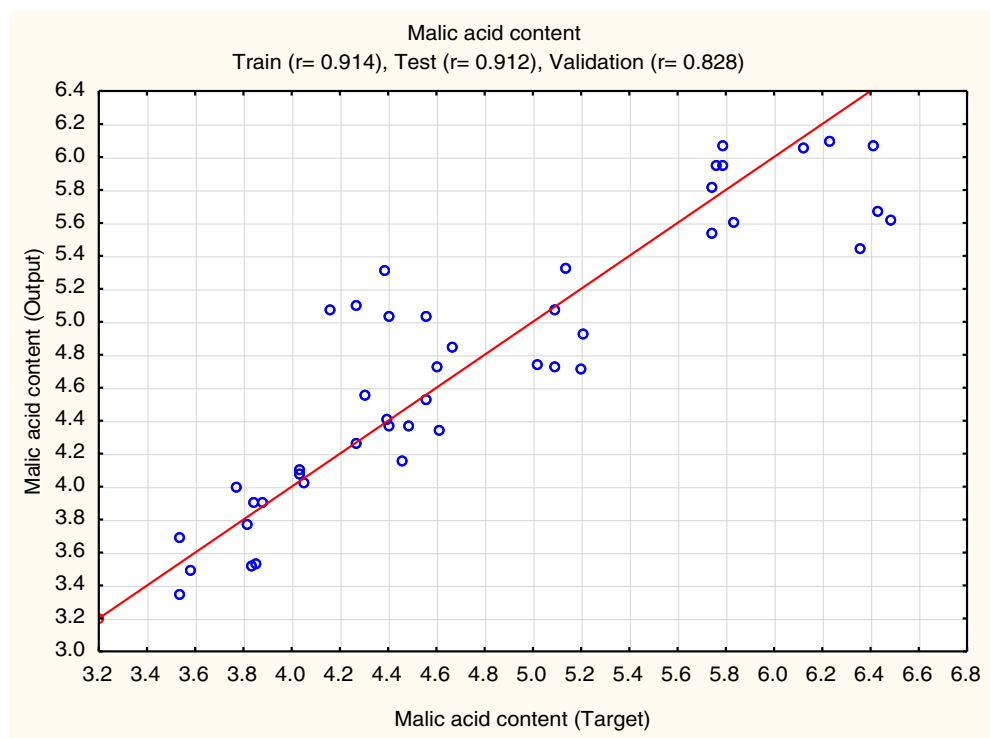

Fig. 3 Correlation between target (observed) and output (simulated) concentrations of malic acid using ANN model

biological reason for malic acid accumulation is not clear in $R$. glacialis. Secale cereale leaves have enhanced malic acid content when acclimated to low temperature (Crecelius et al. 2003; Streb et al. 2005).

First three components of principal component analysis accounted for $99.97 \%$ of the total variance $(95.90,3.98$, and $0.097 \%)$. Factor analysis was also applied to organic acid contents (Table 2). Factor- 1 accounted for $42.4 \%$ of the total variance and had maximum loadings on succinic and fumaric acids both being intermediates of the tricarboxylic acid (TCA) cycle. Factor-2 had maximum loadings on citric acid (source) and malic acid (sink) and explained $38.9 \%$ of the total variance (Fig. 2a, b). Multiple linear regression analysis (MLR) was applied to different organic acids (Table 3). From the MLR, it was revealed that citric and succinic acids contribute positively to the malic acid content, whereas fumaric acid had a negative regression with the malic acid. Beta regression coefficients ( $\beta$ coefficient) reveal the relative importance of different independent variables on the dependent variable (malic acid). The acid maximum contributing to formation of malic acid was citric acid, followed by succinic acid. Path analysis of the effects of different acids on malic acid content revealed that citric acid has maximum direct effect on malic acid. The total effects of succinic and fumaric acids on malic acid are negligible.

The ANN model was developed by taking malic acid as a dependent variable, and citric, succinic, and fumaric acids as independent variables using the Statistica-12 software (Fig. 3). ANN consisted of one hidden layer, tanh transfer function, and three neurons. The number of neurons is generally 70 to $90 \%$ of the input layer size (Boger and Guterman 1997). Correlation between target and output values of malic acid was found to be highly significant: training $(r=0.914)$, test $(r=0.912)$, and validation $(r=0.828)$.

The TCA cycle may be treated to be a system having four components in which the output from a component becomes an input for the next component (Fig. 4).The rate of transformation of citric acid $\left(x_{1}\right)$ to succinic acid $\left(x_{2}\right)$ then to fumaric acid $\left(x_{3}\right)$ and finally to malic acid $\left(x_{4}\right)$ may be characterized by rate transfer coefficients a, b, and c, respectively. Malic acid is then utilized for other metabolic pathways at a rate (d). Igamberdiev and Eprintsev (2016) discussed the organic acid metabolism in plants in the context of redox regulation. In a TCA cycle, two acids, citric acid and malic acid, are generally the most accumulated organic acids in plants. In the

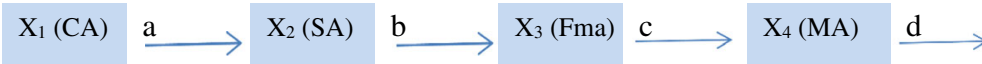

Fig. 4 Conversion of citric acid to malic acid. $x_{i}$ represent concentrations of the acids and a, b, c, and d are the rate transfer coefficients 
Table 4 Rate transfer coefficients of the difference equation for different organic acids

\begin{tabular}{lllll}
\hline Plant species & $\mathrm{a}$ & $\mathrm{b}$ & $\mathrm{c}$ & $\mathrm{d}$ \\
\hline Ranunculus sceleratus & 0.12 & 0.82 & 1.23 & 0.059 \\
Argemone mexicana & 0.18 & 0.60 & 1.04 & 0.100 \\
Fumaria parviflora & 0.17 & 0.71 & 1.37 & 0.099 \\
Oxalis corniculata & 0.16 & 0.65 & 1.43 & 0.100 \\
Ageratum conyzoides & 0.08 & 0.51 & 1.03 & 0.100 \\
Erigeron bonariensis & 0.15 & 0.70 & 1.38 & 0.100 \\
Parthenium hysterophorus & 0.16 & 0.70 & 1.38 & 0.075 \\
Chenopodium album & 0.10 & 0.68 & 1.13 & 0.100 \\
Chenopodium ambrosioides & 0.15 & 0.69 & 1.23 & 0.086 \\
Polygonum barbatum & 0.11 & 0.50 & 0.89 & 0.100 \\
Polygonum plebeium & 0.12 & 0.57 & 0.88 & 0.100 \\
Rumex dentatus & 0.02 & 0.15 & 0.26 & 0.008 \\
Tamarix dioica & 0.16 & 0.74 & 1.17 & 0.100 \\
Cannabis sativa & 0.02 & 0.13 & 0.27 & 0.009 \\
Typha angustata & 0.14 & 0.59 & 1.28 & 0.100 \\
Average & 0.12 & 0.59 & 1.08 & 0.082 \\
\hline
\end{tabular}

present paper, the transfer rates of citric acid to malic acid via succinic acid and fumaric acid were calculated. The conversion of citric acid to malic acid may be simulated in terms of system analysis. The rates of transformation of different acids in this system are represented by $a, b, c$, and $d$. Assuming that the reactions involved in the process occur at a constant rate, the concentrations of the organic acids will achieve a steady state (Easterby 1996; Fridlyand and Scheibe 1999).

Since biological systems follow homeostatic mechanisms, and have a strong resilience, it was presumed that the transformation of acids will follow a system of damped oscillations to achieve steady state within the minimum possible time. It was found by simulation that the value of $x_{3}$ (fumaric acid) shows maximum oscillations on increase in the value of the rate coefficient $d$.
The value of $d$ was varied for each plant species, and the variance between the simulated value of fumaric acid with respect to the steady state value was calculated. The simulated value of $d$ at which the minimum variance with respect to the value of $x_{3}$ for 10 cycles, from the 3rd cycle (when the first formation of fumaric acid would occur) to the 12th cycle, was used to estimate the rate transfer coefficients of the difference equations (Table 4). It is seen from the transfer functions that the ratio of the concentrations of two organic acids is inversely proportional to the rates of their transfers. Figures 5 and 6 show the simulation plots for succinic acid, fumaric acid, and malic acid and the transformation coefficients from citric to malic acids for average concentrations of acids in the leaves of plants. The value of the rate constant $d$ gives the rate of utilization of malic acid formed in TCA for energy production. It is seen from Fig. 7 that the rates of conversion of different acids are directly proportional to the rate of utilization of malic acid by the plants which helps the plants to achieve homeostasis for maintaining desired concentrations of acids in plants. The system however becomes unstable if the value of $d$ increases to 0.13 (sustained oscillations) or 0.14 or higher (negatively damped oscillations). This would lead to changes in the compartment sizes of different acids. High contents of malic acid in the leaves of $R$. dentatus and $C$. sativa can be attributed to the low rate of utilization of malic acid $(d)$ in these species. Difference equation and matrix models are important techniques for population growth (Poole 1974; Svirezhev and Logofet 1983), cell division, and enzyme catalyzed reactions (Thukral et al. 2001). In the present study, it has been shown that organic acids in the TCA cycle can be modeled using various techniques, viz., factor analysis, multiple linear regression, system analysis, and neural networks.

\section{Conclusions}

The present study revealed that the average values of citric, succinic, fumaric, and malic acids found in the leaves

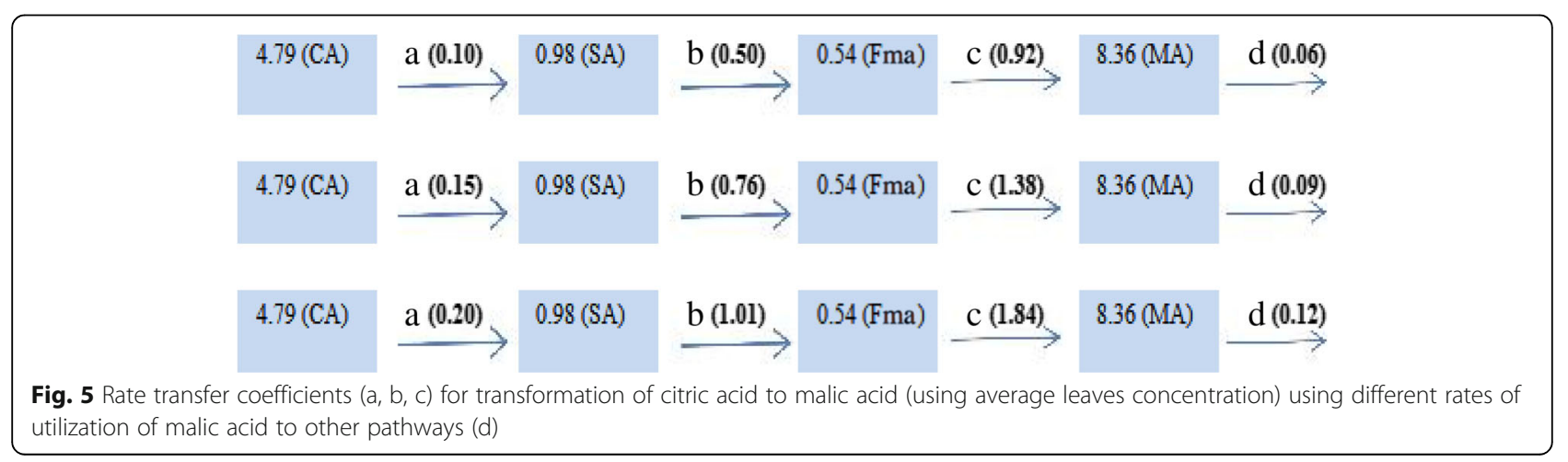




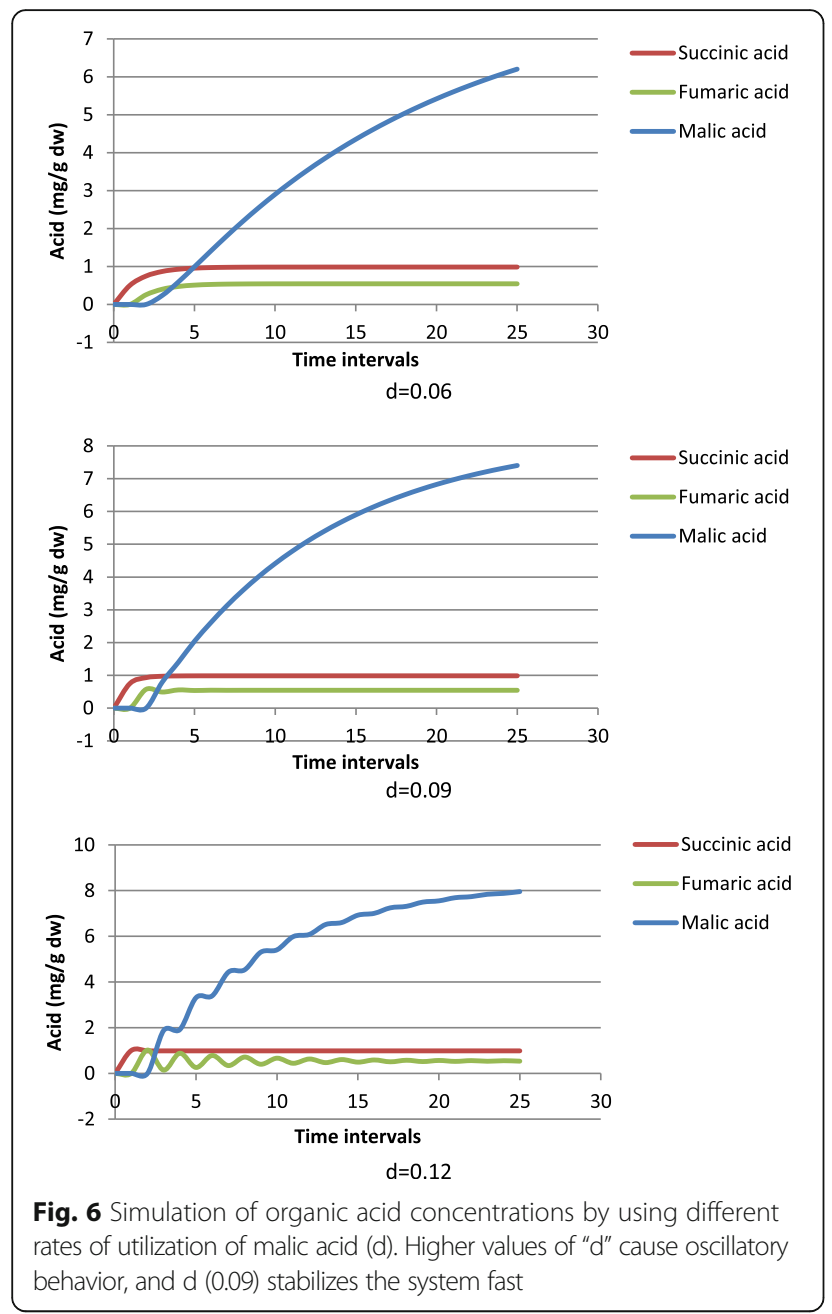

of 15 plant species were $4.79,0.98,0.54$, and $8.36 \mathrm{mg} / \mathrm{g}$ $\mathrm{dw}$, respectively. Factor analysis explained two underlying factors: Factor-1 (succinic acid and fumaric acid) and Factor-2 (citric acid and malic acid). Multiple linear regression analysis showed that citric and succinic acids are positively regressed on the malic acid, whereas

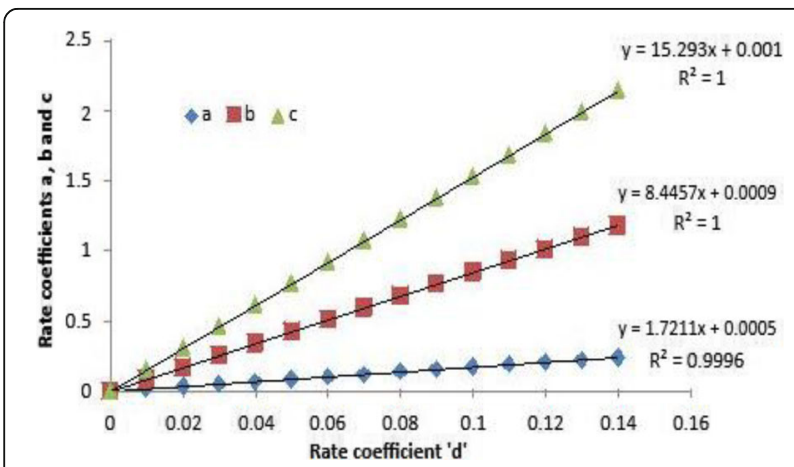

Fig. 7 Increase in rate of conversion of CA (a), SA (b), and FmA (c) with increase in rate of utilization of MA (d) fumaric acid had negative regression with the malic acid. ANN models were fitted to the data. Simulation graphs were also fitted to the average values of different organic acids by using difference equations. The system attains homeostasis by changing the values of transfer coefficients in response to the rate of utilization of malic acid.

\section{Abbreviations}

ANN: Artificial neural network analysis; CA: Citric acid; FA: Factor analysis; FmA: Fumaric acid; GC-MS: Gas chromatography-mass spectrometry; MA: Malic acid; MLR: Multiple linear regression analysis; PCA: Principal component analysis; SA: Succinic acid

\section{Acknowledgements}

Not applicable

\section{Authors' contributions}

This work was carried out in collaboration between all authors. Author VK collected and analyzed the plant samples. Authors VK and AS carried out literature search and drafted the manuscript. Authors RB and AKT designed the experiment and statistically analyzed the data. All authors read and approved the final manuscript.

\section{Funding}

Not applicable

\section{Competing interests}

The authors declare that they have no competing interests.

\section{Publisher's Note}

Springer Nature remains neutral with regard to jurisdictional claims in published maps and institutional affiliations.

Received: 1 September 2017 Accepted: 24 October 2017

Published online: 30 October 2017

\section{References}

Adamczak A, Buchwald W, Zieliński J, Mielcarek S. Flavonoid and organic acid content in Rose hips (Rosa L., sect. Caninae DC. EM. Christ.). Acta Biol Crac Ser Bot. 2012:54:105-12.

Arias-Carmona MD, Romero-Rodríguez MÁ, Vázquez-Odériz ML. Determination of organic acids in Brassica rapa L. leaves (turnip greens and turnip tops) regulated by the protected geographical indication "Grelos De Galicia". J Food Nutr Res. 2014:2:786-91.

Bailey NTJ. Statistical methods in biology. Cambridge: Cambridge University Press; 1994. Baldwin EA. Fruit flavor, volatile metabolism and consumer perceptions. Fruit quality and its biological basis. Sheffield: Sheffield Academic Press; 2002.

Bennet-Clark TA. The role of the organic acids in plant metabolism. Part I. New Phytol. 1993;32:37.

Boger Z, Guterman H. Knowledge extraction from artificial neural network model: Orlando, IEEE systems, man and cybernetics Conference; 1997.

Campo G, Berregi I, Caracena R, Santos Jl. Quantitative analysis of malic and citric acids in fruit juices using proton nuclear magnetic resonance spectroscopy. Anal Chim Acta. 2006;556:462-8.

Carocho M, Barros L, Antonio AL, Barreira JC, Bento A, Kaluska I, Ferreira IC. Analysis of organic acids in electron beam irradiated chestnuts (Castanea sativa Mill.): effects of radiation dose and storage time. Food Chem Toxicol. 2013;55:348-52.

Crecelius F, Streb P, Feierabend J. Malate metabolism and reactions of oxido reduction in cold-hardened winter rye (Secale cereale L.) leaves. J Exp Bot. 2003;54:1075-83.

Destandau E, Vial J, Jardy A, Hennion MC, Bonnet D, Lancelin P (2005). Development and validation of a reversed-phase liquid chromatography method for the quantitative determination of carboxylic acids in industrial reaction mixtures. J Chromatogr A 2005;1088:49-56.

Easterby $\mathrm{J}$. The fusion of control analysis and temporal analysis of metabolic systems. J Theor Biol. 1996;182:327-31. 
Fridlyand LE, Scheibe R. Regulation of the Calvin cycle for CO2 fixation as an example for general control mechanisms in metabolic cycles. Biosystems. 1999;51:79-93.

Igamberdiev AU, Eprintsev AT. Organic acids: the pools of fixed carbon involved in redox regulation and energy balance in higher plants. Front Plant Sci. 2016;7 https://doi.org/10.3389/fpls.2016.01042.

Kader AA. Flavor quality of fruits and vegetables. J Sci Food Agric. 2008;88:1863-8.

Kumar V, Sharma A, Chawla A, Bhardwaj R, Thukral AK. Water quality assessment of river Beas, India, using multivariate and remote sensing techniques. Environ Monit Assess. 2016;188:1-10.

Kumar V, Sharma A, Dhunna G, Chawla A, Bhardwaj R, Thukral AKA. Tabulated review on distribution of heavy metals in various plants. Environ Sci Pollut Res. 2017;10:1-51.

Kumar V, Sharma A, Thukral AK, Bhardwaj R. Polyphenols profiling in the leaves of plants from the catchment area of river Beas. Int J Phar Biosci. 2015a;6:1005-12.

Kumar V, Sharma A, Thukral AK, Bhardwaj R. Amino acid profiling of the leaves of plants in the vicinity of river Beas, India. J Chem Pharma Res. 2015b;7:504-10.

Nogués S, Tcherkez G, Streb P, Pardo A, Baptist F, Bligny R, Ghashghaie J, Cornic G. Respiratory carbon metabolism in the high mountain plant species Ranunculus glacialis. J Exp Bot. 2006;57:3837-45.

Poole RW. An introduction to quantative ecology. New York: McGraw Hill; 1974

Roriz CL, Barros L, Carvalho AM, Ferreira IC. HPLC-profiles of tocopherols, sugars, and organic acids in three medicinal plants consumed as infusions. Int J Food Sci. 2014; https://doi.org/10.1155/2014/241481

Sánchez-Mata MC, Loera RC, Morales P, Fernández-Ruiz V, Cámara M, Marqués $C D$, Pardo-de-Santayana M, Tardío J. Wild vegetables of the Mediterranean area as valuable sources of bioactive compounds. Genet Res Crop Evol. 2012;59:431-43.

Sharma A, Thakur S, Kumar V, Kanwar MK, Kesavan AK, Thukral AK, Bhardwaj R, Alam P, Ahmad P. Pre-sowing seed treatment with 24-epibrassinolide ameliorates pesticide stress in Brassica juncea L. through the modulation of stress markers. Front Plant Sci. 2016;7 https://doi.org/10.3389/fpls.2016.01569. Sokal RR, Rohlf FJ. Biometry. New York: W. H. Freeman; 1995.

Streb P, Josse E, Gallouet E, Baptist F, Kuntz M, Cornic G. Evidence for alternative electron sinks to photosynthetic carbon assimilation in the high mountain plant species Ranunculus glacialis. Plant Cell Envir. 2005;28:1123-35.

Svirezhev YM, Logofet DO. Stability of biological communities. Moscow: Mir; 1983.

Thukral AK, Singh J, Garg AK. Matrix models for phase transformation during cell division and enzyme catalysed reaction. In: Current trends in information theory, statistics and O.R., Ed. Om Parkash. Amritsar: Guru Nanak Dev University, 2001; 255-259.

\section{Submit your manuscript to a SpringerOpen ${ }^{\circ}$ journal and benefit from:}

- Convenient online submission

- Rigorous peer review

Open access: articles freely available online

- High visibility within the field

Retaining the copyright to your article

Submit your next manuscript at $>$ springeropen.com 